\title{
PENGEMBANGAN MEDIA PEMBELAJARAN MULTIMEDIA INTERAKTIF MATA KULIAH PERAWATAN KULIT WAJAH
}

\author{
Murni Astuti ${ }^{1)}$, Rahmiati $^{2)}$, Sri Zulfia Novita ${ }^{3)}$, Rahmi Oktarina $^{4)}$ \\ 1, 2 Prodi Pendidikan Tata Rias dan Kecantikan, \\ ${ }^{3}$ Prodi Pendidikan Kesejahteraan Keluarga, \\ Fakultas Pariwisata dan Perhotelan,Universitas Negeri Padang \\ e-mail : $\underline{{ }^{1} \text { murniastuti@fpp.unp.ac.id, }, \text { rahmiati@fpp.unp.ac.id, }{ }^{2} \text { rahmiati@fpp.unp.ac.id }}$ \\ ${ }^{4}$ rahmyoktarina2016@gmail.com
}

\begin{abstract}
Learning Skin Care is one of the compulsory subjects in the Department of Beauty And Cosmetology FPP UNP. The problems encountered in learning Facial Skin Care are students having difficulty in understanding massage tehnic and problematic facial care techniques with technology. This causes student learning outcomes are relatively low. The purpose of this research is to develop interactive multimedia learning media on Facial Skin Care courses that are practical, valid and effective. This research was conducted in the cosmetology and beauty department of FPP UNP. This research uses the Research and Development $(R \& D)$ research method. Interactive multimedia validation of Facial Skin Care courses conducted by material validators and media and language display an average of $3.68 \%$ with the category "very valid" Whereas the practicality of interactive multimedia seen from the response of lecturers who get an average of $3.60 \%$ and students $3.79 \%$. This shows the interactive multimedia Facial Skin Care, including the category "very practical".
\end{abstract}

Keywords: Interactive Multimedia, Facial Skin Care subject

\section{INTISARI}

Pembelajaran Perawatan Kulit Wajah merupakan salah satu mata kuliah wajib yang ada pada Jurusan Tata Rias dan Kecantikan Universitas Negeri Padang. Permasalahan yang ditemui pada pembelajaran Perawatan Kulit Wajah adalah mahasiswa mengalami kesulitan dalam memahami teknik pengurutan wajah, dan teknik perawatan wajah bermasalah dengan tehnologi. Hal ini menyebabkan hasil belajar mahasiswa relatif rendah. Tujuan dari penelitian ini adalah mengembangkan media pembelajaran multimedia interaktif pada mata kuliah Perawatan Kulit Wajah yang praktis ,valid dan efektif. Penelitian ini dilakukan di jurusan tata rias dan kecantikan FPP UNP. Penelitian ini menggunakan metode penelitian pengembangan Researd and Development (R\&D).Validasi multimedia interaktif mata kuliah Perawatan Kulit Wajah dilakukan oleh validator materi dan tampilan media dan bahasa memperoleh rata-rata 3,68\% dengan kategori"sangat valid" Sedangkan kepraktisan multimedia interaktif dilihat dari respon dosen yang memperoleh rata-rata 3,60\% dan mahasiswa 3,79\%.Hal ini menunjukkan multimedia interaktif Perawatan Kulit Wajah termasuk kategori "sangat praktis".

Kata kunci : Multimedia Interaktif, Mata Kuliah Perawatan Kulit Wajah

\section{PENDAHULUAN}

Kualitas pendidikan, sangat ditunjang oleh peran dosen sangat menentukan dalam menyelenggarakan proses pembelajaran yang berkualitas. Salah satu cara yang dilakukan dosen untuk membantu mahasiswa dalam mencapai hasil belajar yang maksimal antara lain dengan penggunaan metode pembelajaran yang menyenangkan dan penerapan media pembelajaran yang menarik dan inovatif agar mahasiswa tidak mudah bosan dan memudahkan penguasaan materi yang disampaikan dosen 
(Anderson, 1987 : 164). Pemanfaatan tehnologi dalam pembelajaran dapat meningkatkan minat mahasiswa salah satunya adalah mengembangkan media pembelajaran berbasis multimedia interaktif pada mata kuliah perawatan kulit wajah.

Perawatan Kulit Wajah merupakan salah satu mata kuliah wajib yang ada pada Jurusan Tata Rias dan Kecantikan Fakultas Pariwisata dan Perhotelan Universitas Negeri Padang. Mata kuliah Perawatan Kulit Wajah khususnya selama ini, dosen menyampaikan materi dengan media pembelajaran powerpoint, buku, dan joobshet. Namun mahasiswa masih sulit untuk memahami dan mengaplikasikan teori tentang perawatan kulit wajah.

Berdasarkan pengamatan penulis saat mengampu mata kuliah Perawatan Kulit Wajah semester Januari-Juni 2017, mahasiswa kesulitan memahami konsep perawatan wajah, melakukan pengurutan wajah, dan melakukan teknik perawatan wajah bermasalah. Hal ini menyebabkan hasil belajar mahasiswa relatif rendah.Kesulitan mahasiswa memahami materi pada mata kuliah perawatan kulit wajah berdampak pada perolehan hasil belajar mahasiswa yang relatif rendah. Perolehan hasil praktek mata kuliah Perawatan Kulit Wajah materi pengurutan wajah dan perawatan kulit wajah bermasalah dengan menggunakan tehnologi dapat dilihat pada tabel 1 .

Tabel 1. Nilai Praktek Mata Kuliah Perawatan Kulit Wajah Semester Januari-Juni 2017

\begin{tabular}{|c|c|c|c|c|}
\hline No. & Materi & Nilai & $\begin{array}{c}\text { Jumlah } \\
\text { Mahasiswa }\end{array}$ & $\%$ \\
\hline $1 \quad \begin{array}{l}\text { Perawatan } \\
\text { kulit wajah } \\
\text { bermasalah } \\
\text { dengan } \\
\text { tehnologi }\end{array}$ & 75 & 15 & 60 \\
\cline { 2 - 4 } & $>75$ & 10 & 40 \\
\hline \multicolumn{3}{|c|}{ Jumlah Total Mahasiswa } & 25 & \\
\hline
\end{tabular}

Berdasarkan tabel 1 terlihat bahwa nilai praktek mahasiswa yang memperoleh nilai 75 berjumlah 15 orang $(60 \%)$ sedangkan yang memperoleh nilai diatas 75 hanya 10 orang $(40 \%)$.

Untuk meningkatkan kualitas pembelajaran sesuai dengan perkembangan tehnologi, dosen dituntut untuk mengembangan media pembelajaran multimedia interaktif yang dapat meningkatkan gairah belajar mahasiswa. Media pembelajaran yang menarik dan interaktif dapat meningkatkan hasil belajar dan minat belajar mahasiswa.( Andrea Garavaglia and Simona Ferrari, 2012).
Oleh karena itu dalam proses pembelajaran Perawatan Kulit Wajah sangat diperlukan media pembelajaran berbasis multimedia interaktif berupa gambar, teks dan animasi, video, tes interaktif yang menarik dan membantu mahasiwa belajar mandiri. Tuntutan global menuntut dunia pendidikan untuk selalu mengikuti perkembangan teknologi sebagai upaya untuk meningkatkan mutu pendidikan (Rusman dkk, 2012).

Dengan demikian penulis berminat untuk meneliti dengan judul " Pengembangan Media Pembelajaran Multimedia Interaktif pada Mata Kuliah Perawatan Kulit Wajah.”

\section{METODE PENELITIAN}

Pada penelitian ini bertujuan untuk merancang media pembelajaran multimedia interaktif pada mata kuliah perawatan kulit wajah yang valid, praktis dan efektif. Diharapkan dengan penggunaan multimedia interaktif pada mata kuliah perawatan kulit wajah yang valid, praktis dan efektif sebagai alat bantu belajar mahasiswa. Mahasiswa dapat belajar tanpa harus bertatap muka dan dapat membuka materi dalam bentuk multimedia interaktif sehingga pembelajaran lebih menarik. Multimedia interaktif yang dikembangkan di fokuskan pada materi pengurutan wajah dan merawat kulit wajah bermasalah. Multimedia interaktif dapat meningkatkan kemampuan belajar mahasiswa. Adri dan Azhar (2008) dalam makalah Pengembangan Paket Multimedia Interaktif Sebagai Sarana Belajar Mandiri Mahasiswa menunjukkan hasil penelitian bahwa E-Media Fisika Terapan dapat meningkatkan kemampuan belajar mandiri mahasiswa, sehingga memberikan keluwesan dan kebebasan bagi mahasiswa dalam mengeksplorasi kemampuannya secara mandiri. Penelitian Astuti,mengemukaan bahwa multimedia interaktif sangat efektif untuk meningkatkan hasil belajar mahasiswa pada mata kuliah keriting dan cat rambut (Astuti:2013).

\section{Model Pengembangan}

Model pengembangan multimedia interaktif mata kuliah Perawatan Kulit Wajah ini dikembangkan dengan model pengembangan 4D dengan tahap yaitu define, design, develop, dandissiminate (Thiagarajan, dkk, dalam Trianto, 2009:189). Model four D (4-D models) terdiri dari tahap pendefenisian (define), perencanaan (design), pengembangan (develop) dan penyebaran (disseminate). Model four D merupakan model pengembangan yang diadaptasi dari Kemp karena lebih mudah dilakukan revisi. Tahap pendefenisian 
merupakan awal pengembangan yaitu berdasarkan analisis kebutuhan terhadap produk yang dikembangkan untuk menyempurnakan praktek yang sudah dilakukan sebelumnya.

\section{Prosedur Pengembangan}

Langkah - langkah pengembangan multimedia interaktif mata kuliah Perawatan Kulit Wajah dalam penelitian ini digambarkan dalam diagram dibawah ini :

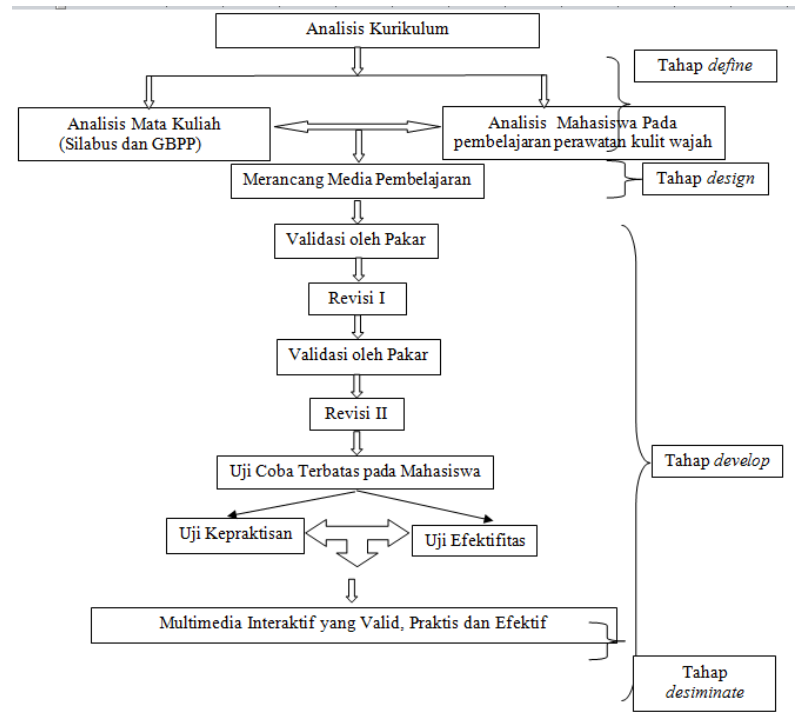

Gambar 1. Diagram rancangan multimedia interaktif

a. Tahap define terdiri dari: analisis Kebutuhan: observasi, analisis mahasiswa dan analisis materi dan media yang akan dikembangkan.

b. Tahap develop: merancang media pembelajaran dengan melakukan Validasi media (materi,syarat konstruksi, tampilan media).

c. Tahap evaluate : uji efektivitas media terhadap kelompok kecil.

Setelah tahap-tahap ini dilakukan maka multimedia interaktif dapat dikatakan valid.praktis dan efektif.

\section{Subjek Penelitian}

Subjek penelitian dalam pengembangan multimedia interaktif ini adalah 25 orang mahasiswa yang mengambil mata kuliah Perawatan Kulit Wajah Jurusan Tata Rias dan Kecantikan FPP Universitas Negeri Padang semester Januari-Juni 2018.

\section{Teknik Analisa Data}

Data yang diperoleh dari hasil validasi dan data yang diambil dari pelaksanaan uji coba dianalisis dengan tekniknya masing-masing.

\section{Analisis data hasil validasi media}

Data hasil validasi media pembelajaran dan hasil pengamatan keterlaksanaan penayangan media dianalisis dengan ketentuan sebagai berikut:

Nilai validitas $=\frac{\text { Jumlah skor yang diperoleh }}{\text { Jumlah skor tertinggi }} \times 100 \%$

Tabel 2. Kategori Validitas Media Pembelajaran

\begin{tabular}{|c|c|c|}
\hline No & Tingkat Pencapaian (\%) & Kategori \\
\hline 1 & $3,50-4,00$ & Sangat valid \\
2 & $3,00-3,49$ & Valid \\
3 & $2,00-2,99$ & Kurang valid \\
4 & $1,00-1,99$ & Tidak valid \\
\hline
\end{tabular}

Sumber: Widjajanti (2008:58)

\section{Analisis data praktikalitas}

Hasil penilaian melalui angket terhadap multimedia interaktif dari dosen dan mahasiswa. Penilaian tersebut akan memperoleh tangapan atau pendapat dari dosen dan mahasiswa untuk menentukan kepraktisan media. Angket terdiri dari pernyataan-pernyaan untuk menentukan kepraktisan media serta disediakan alternatif jawaban terhadap pernyataan-pernyataan tersebut. Alternatif jawaban terdiri dari sangat praktis, praktis, kurang praktis,tidak praktis.

Nilai Praktikalitas $=\frac{\sum \text { Skor yang diperoleh }}{\text { Skor Maksimum ideal }}$ X 100\%

Tabel 3. Kategori Praktikalitas Media Pembelajaran

\begin{tabular}{|c|c|c|}
\hline No & Tingkat Pencapaian (\%) & Kategori \\
\hline 1 & $3,50-4,00$ & Sangat praktis \\
2 & $3,00-3,49$ & Praktis \\
3 & $2,00-2,99$ & Kurangpraktis \\
4 & $1,00-1,99$ & Tidakpraktis \\
\hline
\end{tabular}

Sumber:Widjajanti (2008:58)

Sedangkan data keterpakaian media video oleh mahasiswa diperoleh dengan rumus persentase $(\%)$ :

$$
\mathrm{P}=\frac{F}{N} \mathrm{X} 100 \%
$$

$\mathrm{P}=$ Persentase yang ingin didapat

$\mathrm{F}=$ Jumlah mahasiswa yang memberikan penilaian 
$\mathrm{N}=$ Jumlah mahasiswa keseluruhan (Sugiono, 2010:83)

Setelah data persentase diperoleh lalu dilakukan pengelompokkan sesuai criteria sebagai berikut:

$$
\begin{aligned}
& 90 \%-100 \%=\text { sangat baik } \\
& 80 \%-89 \%=\text { baik } \\
& 65 \%-79 \%=\text { cukup baik } \\
& 55 \%-64 \%=\text { tidak baik } \\
& 0 \%-54 \%=\text { sangat tidak baik } \\
& \text { (Purwanto, 2007:82) }
\end{aligned}
$$

\section{HASIL DAN PEMBAHASAN}

\section{Data Uji Validitas}

Pengambilan data validitas Multimedia interaktif sebagai media pembelajaran adalah dengan menggunakan angket (kuesioner). Dalam hal ini peneliti memberikan angket kepada tiga validator yang memvalidasi media yang dikembangkan. Validator pertama melakukan validasi isi (materi), validasi bahasa dan validator ketiga melakukan validasi tampilan media. Validasi isi (materi) meliputi, Silabus, dan materi yang digunakan dan melihat beberapa aspek penting antara lain ketepatan dalam pengembangan silabus dan materi apakah mengacu pada kurikulum yang digunakan. Validator materi dinilai oleh dosen yang mengajar mata kuliah perawatan kulit wajah yang terdiri dari 3 orang.Validator bahasa dinilai oleh dosen FIP UNP berjumlah satu orang. Sedangkan validator ketiga memberikan pada aspek tampilan media yang dikembangkan oleh dosen FT UNP Jurusan TIK berjumlah satu orang.

Hasil penilaian dari masing-masing aspek indikator yang diberikan validator dijumlahkan dan dihitung persentase penilaian menurut aspek yang telah dibuat. Validasi media merupakan validasi terhadap hasil rancangan produk yang dihasilkan.

Hasil validasi multimedia interaktif dirangkum berdasarkan kategori validasi yang dinilai sebagaimana terlihat pada tabel 4 dibawah ini:

Tabel 4. Hasil Validasi Multimedia Interaktif Perawatan Kulit Wajah

\begin{tabular}{|c|l|c|c|}
\hline No & Aspek Penilaian & $\begin{array}{c}\text { Persentase } \\
\text { penilaian }\end{array}$ & Kategori \\
\hline 1 & Isi/media & 3,66 & Sangat Valid \\
\hline 2 & Syarat konstruk & 3,53 & Sangat Valid \\
\hline 3 & Teknis & 3,85 & Sangat Valid \\
\hline & Rata-rata & $\mathbf{3 , 6 8}$ & Sangat Valid \\
\hline
\end{tabular}

Dari tabel 4 di atas menunjukkan skor rata-rata multimedia interaktif perawatan kulit wajah yang diterima dengan tiga syarat yaitu dari isi materi, syarat konstruk dan tampilan media dapat disimpulkan media tersebut masuk pada kategori "Sangat Valid"

\section{Data Uji Praktikalitas}

\section{a. Data Uji Praktikalitas Berdasarkan Respon paktisi/Dosen}

Praktikalitas berkaitan dengan kemudahan dalam penggunaaan multimedia interaktif yang dikembangkan. Data praktikalitas diperoleh melalui angket yang diisi oleh dua orang dosen mata kuliah perawatan kulit wajah.

Tabel 5. Data Hasil Praktikalitas Multimedia Interaktif Menurut Respon Dosen

\begin{tabular}{|c|l|c|c|c|c|}
\hline \multirow{2}{*}{ No } & \multirow{2}{*}{ Aspek Penilaian } & \multicolumn{2}{|c|}{$\begin{array}{c}\text { Persentase } \\
\text { penilaian }\end{array}$} & \multirow{2}{*}{ Kategori } \\
\cline { 3 - 5 } & & P1 & P2 & Rata2 & \\
\hline 1 & $\begin{array}{l}\text { Kemudahan } \\
\text { Penggunaan }\end{array}$ & 3,73 & 3,80 & 3,76 & Sangat Praktis \\
\hline 2 & Efektifitas waktu & 3,50 & 3,40 & 3,45 & Sangat Praktis \\
\hline 3 & $\begin{array}{l}\text { Penginterpretasian } \\
\text { media }\end{array}$ & 3,70 & 3,50 & 3,60 & Sangat Praktis \\
\hline 4 & Ekivalensi & 3,50 & 3,70 & 3,60 & Sangat Praktis \\
\hline & Rata-rata & & & $\mathbf{3 , 6 0}$ & $\begin{array}{c}\text { Sangat } \\
\text { Praktis }\end{array}$ \\
\hline
\end{tabular}

Keterangan : P1 = Praktisi 1, P2 = Praktisi 2

\section{b. Data Uji Praktikalitas Berdasarkan Respon Mahasiswa}

Untuk praktikalitas media juga memerlukan masukan berupa respon dari mahasiswa dalam kelompok kecil terdiri dari 6 orang melalui angket yang diberikan.

Tabel 6. Rekapitulasi Praktikalitas berdasarkan respon mahasiswa

\begin{tabular}{|c|l|c|c|}
\hline No & Aspek Penilaian & $\begin{array}{c}\text { Persentase } \\
\text { penilaian }\end{array}$ & Kategori \\
\hline 1 & $\begin{array}{l}\text { Kemudahan } \\
\text { Penggunaan } \\
\text { Media }\end{array}$ & 3,75 & Sangat Praktis \\
\hline 2 & $\begin{array}{l}\text { Tampilan dan } \\
\text { daya tarik media }\end{array}$ & 3,80 & Sangat Praktis \\
\hline 3 & Efesiensi Waktu & 3,83 & Sangat Praktis \\
\hline & Rata-rata & $\mathbf{3 , 7 9}$ & Sangat Praktis \\
\hline
\end{tabular}

Berdasarkan hasil pengisian angket keterpakaian multimedia oleh mahasiswa ditinjau 
dari kemudahan penggunaan media,tampilan dan daya tarik media, efesiensi waktu diperoleh ratarata persentase keseluruhan sebasar 3,79\% dengan kategori sangat praktis.

\section{Efektifitas Media}

Pada tahap ini peneliti melakukan pada tahun ke dua dengan menggunakan pembalajaran e learning dengan menggunakan edmodo.

\section{Tampilan Multimedia Interaktif Perawatan Kulit Wajah}

Konten-konten multimedia terdiri dari bagian intro (pembuka), dan menu utama (menu silabus, materi, kuis, about dan keluar). Pada tampilan bagian pembuka (intro) berisi logo UNP dan disertai dengan musik intro. Setelah itu muncul halaman judul penelitian, kemudian personil penelitian yang terdiri dari nama ketua dan anggota. Untuk lebih jelasnya dapat dilihat pada gambar 1, gambar 2 dan gambar 3 dibawah ini:

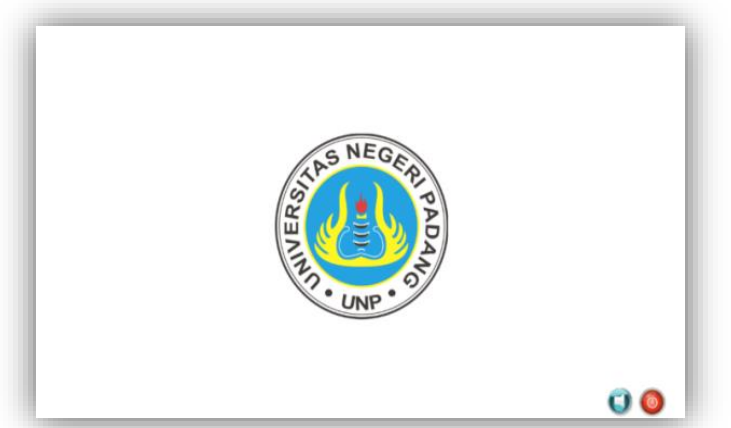

Gambar 1. Tampilan Halaman Pembuka

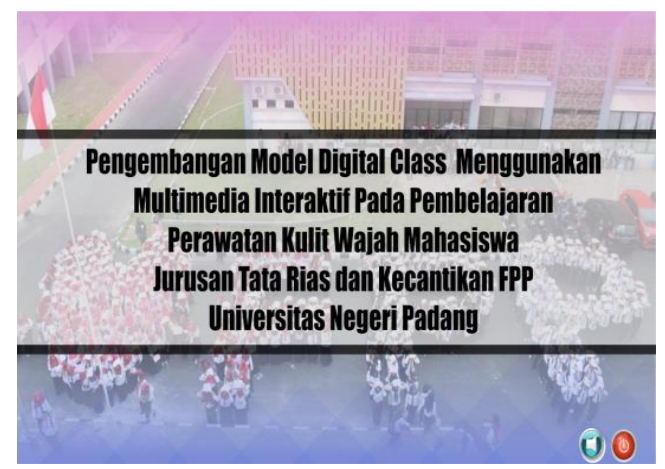

Gambar 2. Tampilan Halaman judul

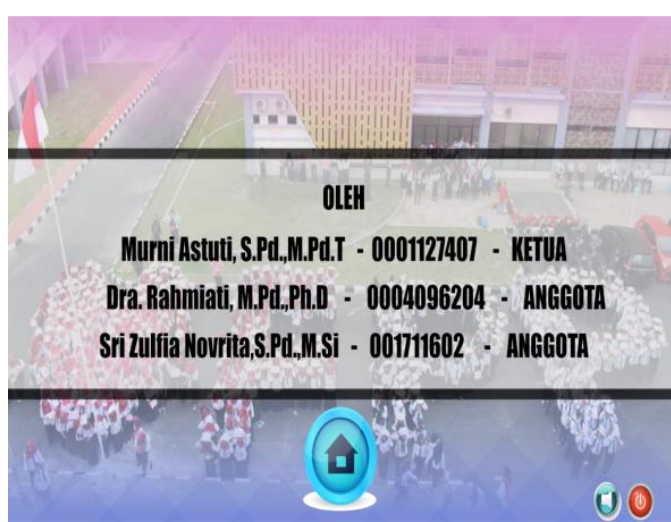

Gambar 3. Tampilan personil penelitian

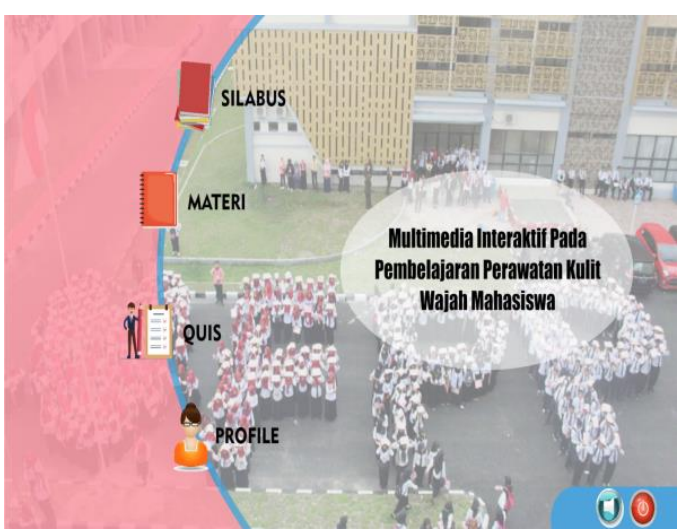

Gambar 4. Tampilan Halaman Menu

Tampilan halaman menu pada gambar 4 ini terdiri dari silabus mata kuliah Perawatan Kulit Wajah,materi,quis,profile Serta menampilkan judul multimedia interaktif pada mata kuliah perawatan kulit wajah.

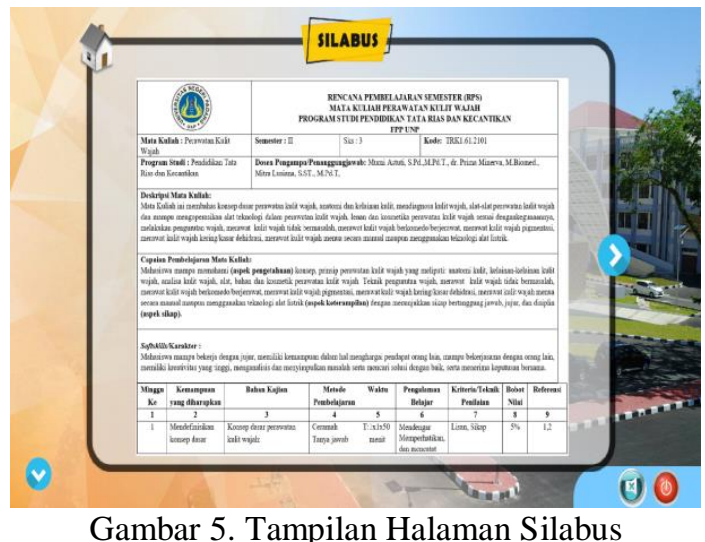

Pada gambar 5 ditampilkan silabus mata kuliah perawatan kulit wajah yang terdiri dari deskripsi mata kuliah, capaian pembelajaran mata kuliah dan materi yang akan diajarkan sampai pertemuan 16. Pada bagian kanan dan kiri terdapat panah yang dapat ditekan untuk halaman sebelum dan sesudah untuk melihat materi silabus. 


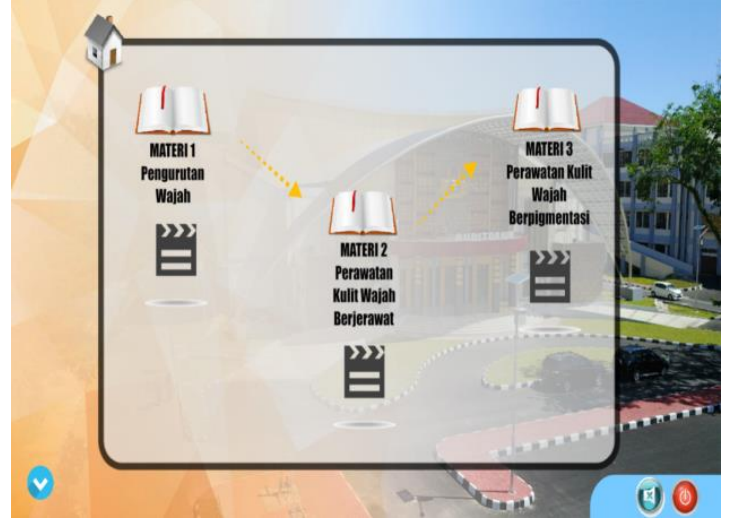

Gambar 6. Tampilan Halaman Materi

Tampilan gambar 6 ini menampilkan materi yang terdiri dari materi 1 yaitu pengurutan wajah yang berbentuk buku berupa power point tentang materi tersebut. Materi 2 Perawatan Kulit Wajah Berjerawat dan materi 3 tentang perawatan kulit wajah berpigmentasi. Materi ini disajikan agar mahasiswa dapat menguasai konsep perawatan kulit wajah. Sedangkan dibagian bawah yang berbentuk video yang menampilkan proses kerja materi 1 tentang pengurutan wajah, materi 2 tentang Perawatan Kulit Wajah Berjerawat dan materi 3 tentang Perawatan Kulit Wajah Berpigmentasi. Video ini ditampilkan dengan tujuan mahasiswa dapat melihat dan meniru secara langsung proses kerja perawatan kulit wajah. Untuk lebih jelasnya dapat dilihat gambar 7 dibawah ini yang merupakan tampilan video pengurutan wajah yang dimulai dari teknik penerima pelanggan dengan ramah dan sopan serta gerakan pengurutan wajah.

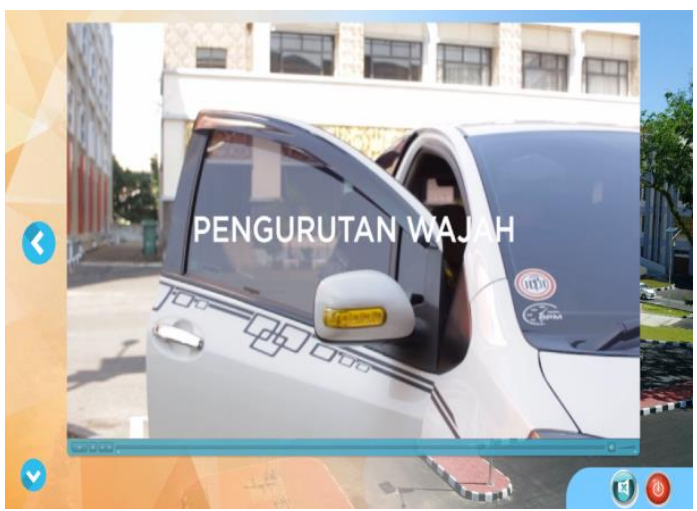

Gambar 7. Tampilan Halaman Video

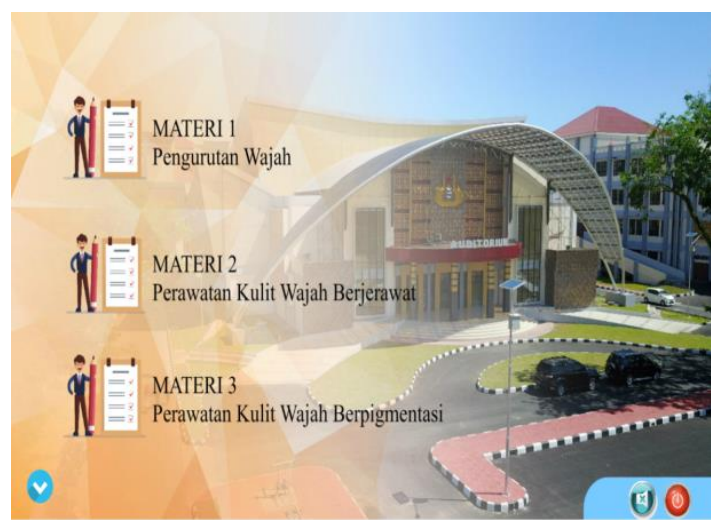

Gambar 8. Tampilan Halaman Quis

Pada gambar 8 terdiri dari quis yang terdiri dari materi 1 tentang pengurutan wajah, materi 2 tentang perawatan kulit wajah berjerawat dan materi 3 tentang perawatan kulit wajah berpigmentasi. Quis ini berisi soal pilihan ganda yang terdiri dari 20 soal yang telah divalidasi oleh ahli materi perawatan kulit wajah.

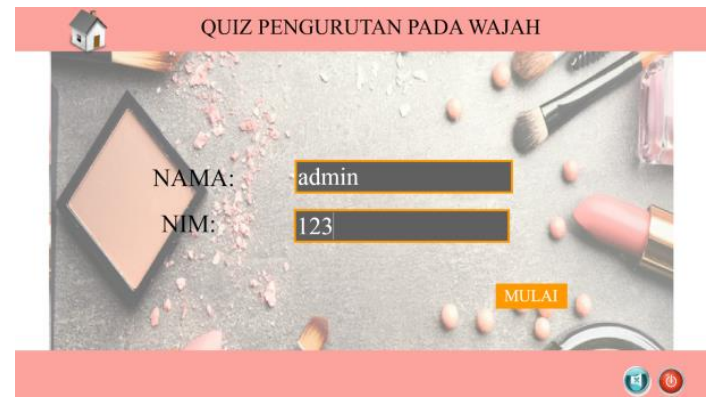

Gambar 9. Tampilan Halaman Quis

Tampilan gambar 9 merupakan data mahasiswa berupa nama dan NIM yang dibawahnya terdapat tombol "mulai".

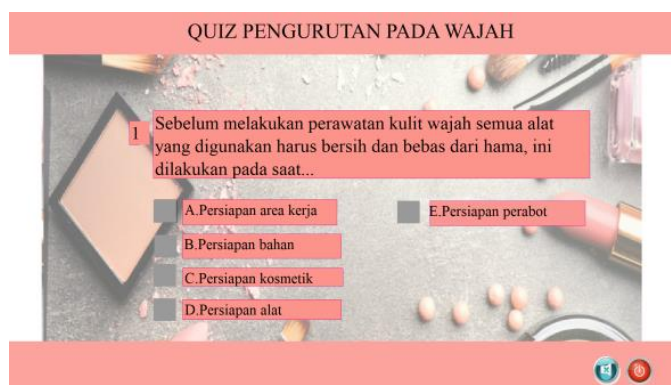

Gambar 10. Tampilan Halaman Quis

Pada gambar 10 merupakan soal pilihan ganda dari materi pengurutan wajah dengan 5 pilihan item jawaban. Pertanyaan tersebut terdiri dari 20 pertanyaan dalam bentuk pilihan ganda. 


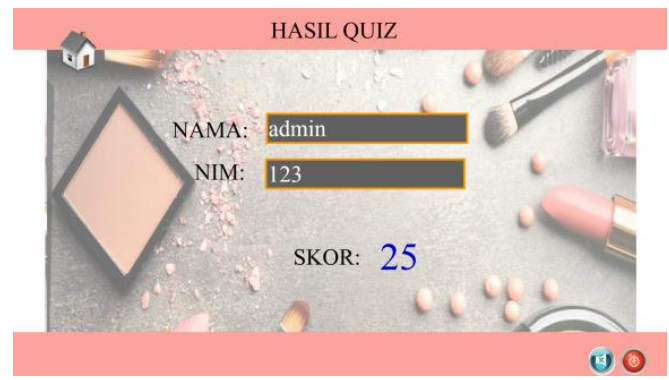

Gambar 11. Tampilan Halaman Hasil Quis

Pada gambar 11 menampilkan perolehan skor nilai mahasiswa setelah menjawab 20 soal dengan skor nilai tertinggi 100 .

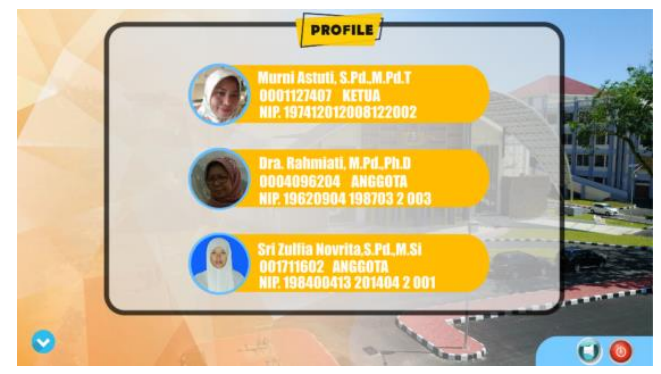

Gambar 12. Tampilan Halaman Profile

Pada gambar 12 menampilkan nama, NIDN, NIP dan foto profil personil penelitian yang terdiri dari 3 orang dosen.

\section{KESIMPULAN}

1. Validasi multimedia interaktif mata kuliah perawatan kulit wajah berdasarkan validasi oleh validator materi, bahasa,tampilan media memperoleh nilai rata-rata 3,68 dengan kategori"sangat valid".

2. Kepraktisan multimedia interaktif pada mata kuliah perawatan kulit wajah berdasarkan respon dosen dengan nilai 3,60\% sedangkan berdasarkan respon mahasiswa memperoleh nilai $3,79 \%$.Hal ini menunjukkan multimedia interaktif yang dikembangkan termasuk kategori"sangat praktis".

\section{DAFTAR PUSTAKA}

[1] Adri, M., \& Azhar, N, "Pengembangan Paket Multimedia Interaktif Sebagai Sarana Belajar Mandiri Mahasiswa", Proceedings Nasional Konstribusi Pendidikan Jarak Jauh (PJJ) dalam Pencapaian Milenium Development Goals (MDGs), Universitas Terbuka Tangerang Banten (Vol. 10), 2008.

[2] Astuti, M., Dewi, I. P., Rahmiati, R., \& Mentari, T. A. S, "Pengembangan Media Pembelajaran Berbasis Multimedia Interaktif Pada Mata Kuliah Keriting Dan Cat Rambut Mahasiswa Jurusan Tata Rias Dan Kecantikan FPP Universitas Negeri
Padang", UNES Journal of Education Scienties, 2(1), 001-009, 2018.

[3] Astuti, M, "Pengembangan Media Pembelajaran Menggunakan Video Mata Kuliah Dasar Tata Rias Program Studi Pendidikan Tata Rias Dan Kecantikan FT UNP", Pakar Pendidikan, 12(2), 118-127, 2014.

[4] Dwi Mahendra, Yoga, "Pengembangan Media E-Modul Berbasis Aplikasi Android Materi Komunikasi Sinkron Dan Asinkron Dalam Jaringan Mata Pelajaran Simulasi Dan Komunikasi Digital Kelas X Multimedia Di SMK Negeri 1 Sooko Mojokerto", Jurnal Mahasiswa Teknologi Pendidikan, 9(2), 2019.

[5] Sriwahyuni, T, "Peningkatan Keterampilan Guru SMA Negeri Dan Swasta Dalam Mengembangkan Media Pembelajaran Berbasis IT Dengan Pendekatan Scientific Learning Se-Kecamatan Tanjung Mutiara, Kabupaten Agam", UNES Journal of Community Service, 3(2), 176-18, 2018.

[6] Purwanto, Ngalim, Psikologi Pendidikan, Remaja Rosdakarya, Bandung, 2007.

[7] Rusman, Belajar dan Pembelajaran Berbasin Komputer: Mengembangkan Profesional Guru Abad 21, Alfabeta, Bandung, 2012.

[8] Sugiyono, Metode Penelitian Pendidikan (Pendekatan Kuantitatif, Kualitatif dan $R \& D)$, Alfabeta, Bandung, 2010.

[9] Trianto, M. P, Mendesain Model Pembelajaran Inovatif-Progresif, Kencana, Jakarta, 2009.

[10] Wena, M, Strategi pembelajaran inovatif kontemporer suatu tinjauan konseptual operasional, Bumi Aksara, Jakarta, 2009. 